\title{
Article \\ Bioactivity of Torch Ginger Umbut Extract (Etlingera elatior) Against Heal Wounds of Mice (Mus musculus)
}

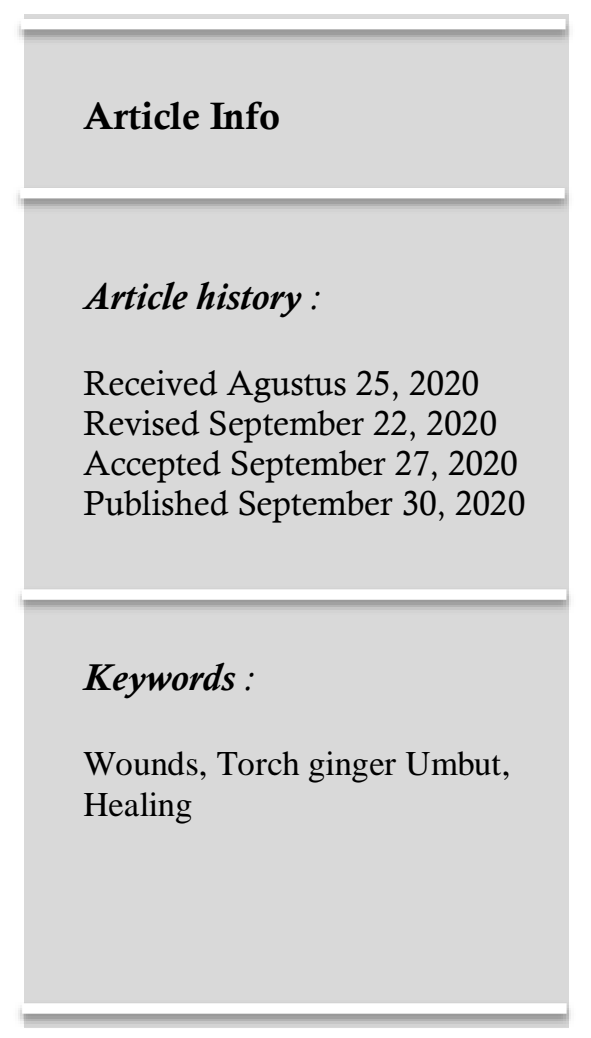

\author{
Mhd Zalil Efendi ${ }^{1}$, Ramadhan Sumarmin ${ }^{1 *}$, M. Syukri Fadil ${ }^{2}$ \\ ${ }^{1}$ Department of Biology, Faculty of Mathematics and Natural \\ Science (FMIPA), Universitas Negeri Padang, Indonesia \\ ${ }^{2}$ Department of Biology, Faculty of Mathematics and Natural \\ Science (FMIPA), Universitas Andalas, Indonesia
}

\begin{abstract}
Torch ginger has a wide range of good antimicrobial, antioxidant, anticancer, larvicidal and repellent activities. Active compounds in Torch ginger that affect pharmacological activities are phenols, polyphenols, flavonoids, and terpenoids. Based on these ingredients Torch ginger can be used to heal wounds. This study aims to observe the effect of Torch ginger Umbut extract on wound healing in mice. This study hopes to add information about the effect of Torch ginger umbut extract on the healing of cuts in mice so that it can be another alternative for wound healing and can be a reference for other researchers. This study used a completely randomized design with 5 treatments and 3 replications. Tests carried out on adult male mice. The results showed that the optimal wound healing in P2 is treatment with $10 \%$ Torch ginger umbut extract which requires a range of wound healing 7-8 days. Based on these results, Torch ginger umbut extract can heal wounds.
\end{abstract}

This is an open acces article under the $\underline{C C-B Y}$ license.

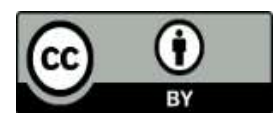

This is an open access article distributed under the Creative Commons 4.0 Attribution License, which permits unrestricted use, distribution, and reproduction in any medium, provided the original work is properly cited. (02020 by author.

\author{
Corresponding Author : \\ Ramadhan Sumarmin \\ ${ }^{1}$ Department of Biology, Faculty of Mathematics and Natural Science (FMIPA), \\ Universitas Negeri Padang, Indonesia \\ Email : ramadhan_sum@,fmipa.unp.ac.id
}

\section{Introduction}

Nowadays the use of medicinal plants has increased both traditionally and modernly. According to the World Health Organization (WHO), more than $80 \%$ of the world's population in developing countries uses medicinal plants for health efforts[1]. Many studies have been carried out using medicinal plants to cure diseases. As in Wulandari and Sumarmin (2018)[2] states that sambiloto extract (Andrographis paniculata) can reduce uric acid levels in mice. The other hands Fitri 
et al (2017)[3] conclude that mangosteen peel extract could decreased uric acid level too. In addition, the use of medicinal plants is also carried out by using red betel leaves where the red betel leaf extract (Piper croatum) can reduce blood glucose levels in mice [4].

Torch ginger is native to Indonesia as evidenced by ethnobotany studies on the island of Borneo, where $70 \%$ of the species have other local names on the island. Torch ginger is included in the zingiberaceae family, this plant is known by various names including "kencong" or "kincung" in North Sumatra, "kecombrang" in Java, "honje" in Sunda, "bongkot" in Bali, "sambuang" in West Sumatra and "Kantan flower" in Malaysia. Western people call this plant a torch ginger or torch lily because of its torch-like flower shape and stunning red color.Some people also call it the Philippine waxflower or porcelein rose in reference to the beauty of its flowers [5].

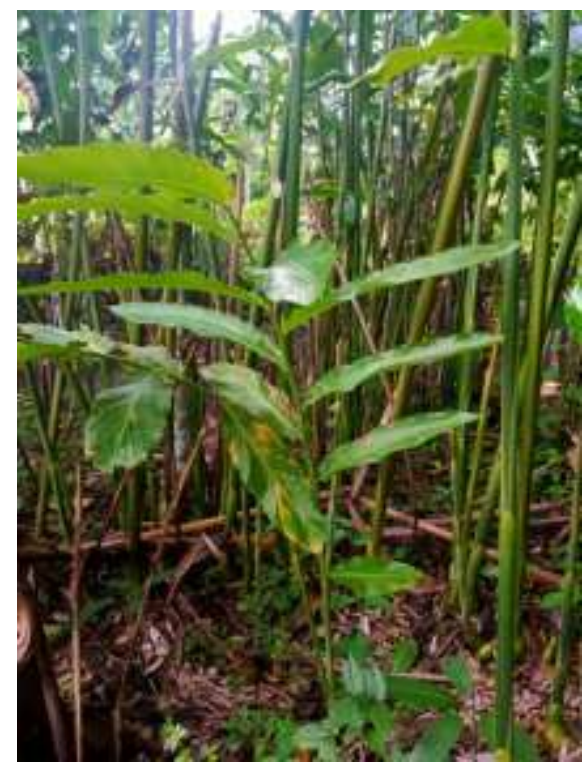

Figure 1. Torch ginger (Etlingera elatior)

Torch ginger has a wide range of bioactivity as a good antimicrobial, antioxidant, anticancer, larvacide and repellent. Active compounds that generally affect pharmacological activity are phenols, polyphenols, flavonoids, and terpenoids. This pharmacological activity occurs with several mechanisms of action in overcoming disease [6]. Some areas in Indonesia, Torch ginger is generally used to increase breast milk, deodorant and is also used as a wound medicine [7]. Based on several studies, it is known that the Torch ginger plant (Etlingera elatior) can heal wounds. In Handayany's (2015) [8] study, the ethanol extract gel formula of Torch ginger flower was effective in healing cuts in rabbits and showed optimum wound healing effects. In Sagala's research (2016) [9] shows that Torch ginger flower extract has an effect in accelerating the healing of incisions.

Injury is a break in the continuity or anatomical connection of the tissue as a result of forced rudaism. According to Ermawan (2019) [10] wounds have several effects on the body, including loss of all or part of organ function, sympathetic stress response, bleeding and blood clots, bacterial contamination and cell death. In response to this damage, the body will try to repair damaged tissue through a wound healing mechanism [11]. Wounds will cause problems if they are not handled properly, causing the wound to be more chronic and become infected. 
In general, the main treatment for giving wounds is generally in the form of debriment, irrigation, and also administration of antibiotics or antiseptics [12]. The antiseptic that is commonly used is povidone iodine, but the use of povidone iodine has side effects that must be considered such as irritation, sunburn, and skin discoloration due to the dye contained in povidone iodine [13].

Based on the above, a research was conducted with the title Effect of Torch ginger umbut extract (Etlingera elatior) on the healing of cuts in mice (Mus musculus). This study aims to determine how the effect of Torch ginger umbut extract (Etlingera elatior) on the healing of cuts in mice (Mus musculus).) as well as to determine the optimal concentration required for wound healing by the extract of Torch ginger Umbut. This research hopes to add information about the effect of Torch ginger tuber extract (Etlingera elatior) on the healing of cuts in mice (Mus musculus) so that it can be another alternative for wound healing and can be a reference material for other researchers.

\section{Experimental Section}

This experiment done as diagram below:

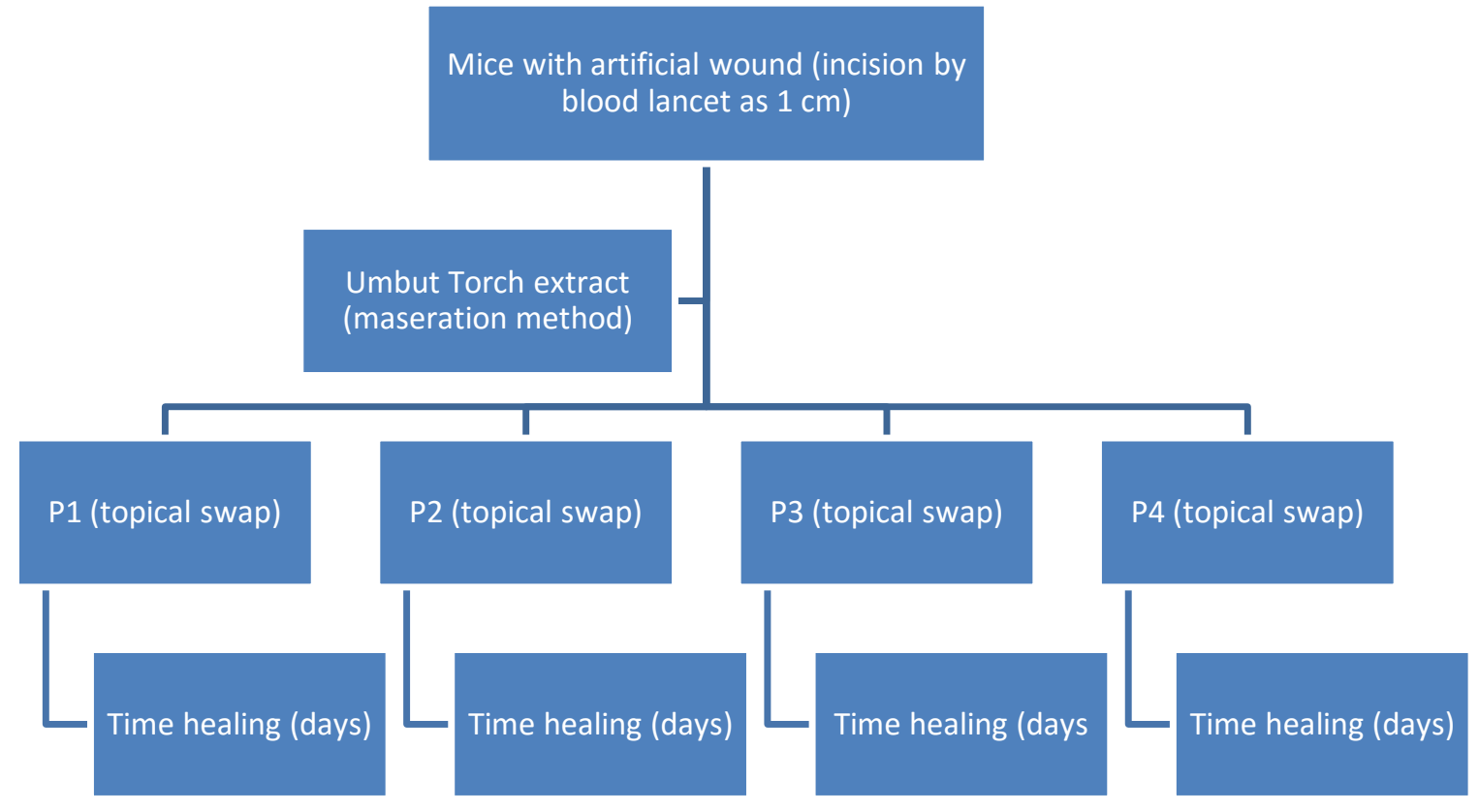

Figure 2. Scheme of experimental section

\subsection{Tools and materials}

The tools used in this study were mouse cages, rotary evaporator, razors, scalpels, erlenmeyers, measuring cups, spatulas, plastic wrap, cameras. The materials used in this study Mus musculus were 15 male, pellet feed, distilled water, rice husks, gauze, plaster, umbut extract of Etlingera elatior, methanol, and povidone iodine 10\%.

\subsection{Preparation of Test Material}

Umbut Etlingera elatior used as research material obtained from Kerinci regency, Jambi. Umbut that has been taken is washed and then dried by being dried in the sun. Next, the dried shredded is weighed as much as $250 \mathrm{~g}$, then placed in a glass bottle and macerated with methanol as much as $2.5 \mathrm{~L}$ or until the umbut is submerged. 
The maceration container is closed and kept in a sun-protected place for 7 days while occasionally stirring. Then filtered, pulp and filtrate are separated.

The filtrate was then concentrated by evaporation using a rotary evaporator until a thick extract of Etlingera elatior was obtained. Extracts obtained were diluted using $0.9 \%$ physiological $\mathrm{NaCl}$ according to the desired concentration.

\subsection{Testing on Animals}

The previously acclimated mice were anesthetized using chloroform, then the hair on the back to be injured was shaved. Subsequently injured with a scalpel with a length of $2 \mathrm{~cm}$ and a depth of 2 $\mathrm{mm}$. The incision wound in group P0 is smeared with povidone iodine. In group P1 the wound was smeared with Torch ginger umbut extract with a concentration of $5 \%$. In group P2 the wound was smeared with Torch ginger umbut extract with a concentration of 10\%. In group P3 the wound was smeared with Torch ginger umbut extract with a concentration of $15 \%$. And in group P4 the wound was smeared with Torch ginger extract with a concentration of $20 \%$. The treatment is given once every 24 hours, then the wound is covered with gauze. Observations were made every day by measuring the length of the wound until the wound healed

\section{Results and Discussion}

Table 1. Time range of wound healing

\begin{tabular}{cc}
\hline Type Treatment & Time Range \\
\hline P0 & 6-7 days \\
P1 & 8-9 days \\
P2 & $7-8$ days \\
P3 & 6-7 days \\
P4 & $6-7$ days \\
\hline
\end{tabular}

Based on further tests with DMRT, there were no significant differences between P0, P2, P3, and P4. It can be concluded that the effectiveness of Torch ginger umbut extract in wound healing is the same as the effectiveness of wound healing by povidone iodine $10 \%$. (table 2 )

Table 2. Further tests with DMRT

\begin{tabular}{cccc}
\hline \multirow{2}{*}{ Type treatment } & $\mathrm{N}$ & \multicolumn{2}{c}{ Subset for alpha $=0.05$} \\
\cline { 3 - 4 } & & 7.0000 & 2 \\
\hline P0 & 3 & 7.0000 & \\
P4 & 3 & 7.0000 & \\
P3 & 3 & 7.3333 & \\
P2 & 3 & & 8.6667 \\
P1 & 3 & .321 & 1.000 \\
Sig. & &
\end{tabular}

Means for groups in homogeneous subsets are displayed.

a. Uses Harmonic Mean Sample Size $=3.000$. 
The process of wound healing by Torch ginger umbut is influenced by the bioactivity of secondary metabolites found in Torch ginger umbut. The content of secondary metabolites such as Alkaloids, flavonoids, tannins, and saponins can act as anti-inflammatory and inhibit infection in wounds. So that the wound healing process can run optimally. The content of antioxidants found in Torch ginger umbut can also function as an immunomodulator so that it can increase the immune response.

The content of flavonoids is responsible through the mechanism of inhibiting free radical activity, and increasing the speed of epithelialization, ascorbic acid content supports the formation of collagen, which immediately after the wound, exposure to collagen fibrils to the blood will cause platelet aggregation and activation and release of chemotaxis factors which start the wound healing process [11].

Flavonoid compounds contain phenol compounds which have the ability to inhibit the formation of pathogenic fungal conidia, denature proteins and damage cell membranes so that it can be said that flavonoid compounds can act as antibacterial agents. According to Yenti (2011) [14]. flavonoids can inhibit bacterial growth by damaging the permeability of bacterial cell walls, microsomes and lysosomes as a result of interactions between flavonoids with bacterial DNA and also being able to release energy transduction to the bacterial cytoplasmic membrane and inhibit bacterial motility. Besides the flavonoid content contained in Torch ginger umbut can function as an analgesic so as to reduce pain.

Tannins function as an astringent that can cause shrinking of the skin pores, harden the skin, stop exudates and bleeding mild, so that it can cover the wound and prevent bleeding that usually arises in the wound [15]. Tannins also function as antioxidants. The tannin content can function as an antiseptic that can prevent damage caused by bacterial and fungal infections. Saponins work by stimulating the formation of new cells, or called Growth Factor. Causing the multiplication and growth of blood vessel endothelial cells, vascular smooth muscle cells and fibroblasts, causing cellular growth which ultimately repair damaged blood vessel walls [16-34].

\section{Conclusion}

Based on the research that has been done, it can be concluded Torch ginger umbut extract (Etlingera elatior) can heal wounds in mice (Mus musculus) and extract concentration of $10 \%$ is sufficiently optimum in healing wound in mice (Mus musculus)

\section{Acknowledgment}

Thanks are conveyed to the head of the Biology laboratory who has given permission to use the laboratory and colleagues who have helped in carrying out the research

\section{References}

1. Canter PH., Thomas H., and Ernst E. (2005). Bringing Medicinal Plants Into Culvitations: Opportunities and Challenges for Biotechnology. Trends in Biotechnology, 180-185. https://doi.org/10.1016/j.tibtech.2005.02.002

2. Wulandari, W., dan Sumarmin R. (2018). The Influence of Bitter Ekstract (Andrographis paniculata Ness.) on Uric Acid Level of Mice (Mus musculus L.) Male. Bio Sains, 21-30. http://dx.doi.org/10.24036/4237RF00

3. Fitri, R.A., Sumarmin, R., and Yuniarti, E. (2017) Effects of mangosteen skin extract (Garcinia mangostana L.) on male mice (Mus musculus L. Swiss Webster) Uric Acid Level. BioScience, Vol. 1 No. 2. pp. 53-61. DOI: https://doi.org/10.24036/bsc.v1i2.7718 
4. Saputra , M. R., Yuniarti E., dan Sumarmin R. (2018). Pengaruh Ekstrak Daun Sirih Merah (Piper croatum Ruiz and Pav.) Terhadap Glukosa Darah Mencit (Mus musculus L.) Jantan yang Diinduksi Sukrosa. Eksakta, 43-55. https://doi.org/10.24036/eksakta/vol19-iss1/124

5. Sukandar, D. (2010). Karakterisasi Senyawa Aktif Antibakteri Ekstrak Air Bunga Kecombrang (Etlingera elatior) Sebagai Bahan Pangan Fungsional. Valensi, 333-339. https://doi.org/10.15408/jkv.v2i1.232

6. Farida,S. (2016). Kecombrang (Etlingera elatior): Sebuah Tinjauan Penggunaan Secara Tradisional, Fitokimia dan Aktivitas Farmakologinya. Badan Litbang, Kementerian Kesehatan RI Volume 9 , 19-28. https://doi.org/10.22435/toi.v9i1.6389.19-28

7. Ningtyas, R. (2010). Uji Antioksidan dan Antibakteri Ekstrak Air daun Kecombrang (Etlingera elatior, Jack) R.M. Smith). UIN Syarif Hidayatullah, 9-10.

8. Handayany, G. (2015). Uji Efek Penyembuhan Luka Sayat Ekstrak Etanol daun Kecombrang (Etlingera elatior) dalam Bentuk Sediaan Gel terhadap Kelinci (Oryctolagus cuniculus). JF FIK UINAM Vol.3 No.2, 54-57. https://doi.org/10.24252/.v3i2.2206

9. Sagala, J. (2016). Pengaruh Ekstrak Etanol Bunga Kecombrang (Etlingera elatior) Terhadap Penyembuhan Luka pada Tikus Putih (Rattus norvegicus). Prosiding Seminar Nasional Tumbuhan Obat indonesia ke-50. https://doi.org/10.25026/mpc.v3i2.114

10. Ermawan,B. (2019). Pengantar patofisiologi untuk mahasiswa diploma keperawatan. Yogyakarta: Pustaka baru.

11. Ariani,S. (2013). Khasiat daun Binahong ( Aredera cordifolia (Ten.) Steenis) Terhadap Pembentukan Jaringan Granulasi dan Reepitelisasi Penyembuhan Luka Terbuka Kulit Kelinci. Jurnal e-Biomedik (eBM), Volume I, Nomor 2., $\quad 914-919$. https://doi.org/10.35790/ebm.1.2.2013.3250

12. Sabirin, Indah PR. (2013). Peran Ekstrak Etanol daun Mengkudu (Morinda citrifolia L.) pada Penyembuhan Luka Ditinjau dari Imunoekspresi CD34 dan Kolagen pada Tikus Galur Wistar. Majalah Kedokteran Bandung Volume 45 no.4, 226-233. https://doi.org/10.15395/mkb.v45n4.169

13. Rahmawati, I. (2014). Perbedaan Efek Perawatan Luka Menggunakan Gerusan Daun Petai Cina (Leucaena glauca, Benth) dan Povidone iodine 10\% dalam Mempercepat Penyembuhan Luka pada Marmut (Cavia porcellus). Jurnal Wiyata, 227-234.

14. Yenti , R. (2011). Formulasi Krim Ekstrak Etanol Daun Kirinyuh(Euphatorium odoratum. L) untuk Penyembuhan Luka. Majalah Kesehatan pharma Medika, 227-230. https://doi.org/10.33476/mkp.v3i1.440

15. Mappa, T. (2013). Formulasi Gel Ekstrak Daun Sasaladahan (Paperomia pellucida L) dan Uji Efektivitasnya terhadap Luka Bakar pada Kelinci (Oryctolagus cuniculus) . Pharmacom, 49-55. https://doi.org/10.35799/pha.2.2013.1606

16. Napanggala, A. (2014). Pengaruh Pemberian Getah Tanaman Jarak Pagar (Jatropha curcas L.) Secara Topikal Terhadap Tingkat Kesembuhan Luka Iris Pada Tikus Putih Jantan Galur Sprague dawley. Medical Journal Of Lampung University, 26-35. https://doi.org/10.21157/jim\%20vet..v1i3.1992

17. Cooper GJ. (2011). Therapeutic potential of copper chelation with triethylenetetramine in managing diabetes mellitus and Alzheimer's disease. Drugs.71(10):1281-320.

18. Dziewulska D, Lewandowska E. (2012). Pericytes as a new target for pathological processes in CADASIL. Neuropathology : official journal of the Japanese Society of Neuropathology.32(5):515-21. 
19. Held F, Morris AWJ, Pirici D, Niklass S, Sharp MMG, Garz C, et al. (2017). Vascular basement membrane alterations and beta-amyloid accumulations in an animal model of cerebral small vessel disease. Clinical science.131(10):1001-13.

20. Hoore M, Rack K, Fedosov DA, Gompper G. (2018). Flow-induced adhesion of shearactivated polymers to a substrate. Journal of physics Condensed matter : an Institute of Physics journal.30(6):064001.

21. Jang TY, Kim YH. (2015). Interleukin-33 and Mast Cells Bridge Innate and Adaptive Immunity: From the Allergologist's Perspective. International neurourology journal.19(3):14250 .

22. Joshi P, Riley DRJ, Khalil JS, Xiong H, Ji W, Rivero F. (2018). The membrane-associated fraction of cyclase associate protein 1 translocates to the cytosol upon platelet stimulation. Scientific reports.8(1):10804.

23. Kawai N, Kobayashi D, Yasui T, Umemoto Y, Mizuno K, Okada A, et al. (2014). Evaluation of side effects of radiofrequency capacitive hyperthermia with magnetite on the blood vessel walls of tumor metastatic lesion surrounding the abdominal large vessels: an agar phantom study. Vascular cell.6:15.

24. Lewis DM, Abaci $\mathrm{HE}, \mathrm{Xu} \mathrm{Y}$, Gerecht S. (2015). Endothelial progenitor cell recruitment in a microfluidic vascular model. Biofabrication.7(4):045010.

25. Li RS, Li DY, Chen WN, Ma XD, Zhang Y, Li XJ. (2014). [Taohong Siwu Decoction regulated functions of endothelial cells and treated arteriosclerosis obliterans: an experimental study]. Zhongguo Zhong xi yi jie he za zhi Zhongguo Zhongxiyi jiehe zazhi $=$ Chinese journal of integrated traditional and Western medicine.34(2):191-6.

26. Li T, Liu X, Ni L, Wang Z, Wang W, Shi T, et al. (2016). Perivascular adipose tissue alleviates inflammatory factors and stenosis in diabetic blood vessels. Biochemical and biophysical research communications.480(2):147-52.

27. Lin D, Lavender H, Soilleux EJ, O'Callaghan CA. (2012). NF-kappaB regulates MICA gene transcription in endothelial cell through a genetically inhibitable control site. The Journal of biological chemistry.287(6):4299-310.

28. Mansour TR, Alam Y, Dahbour L, Alnemari A, Jumaa M, Schroeder JL. (2017). Streptococcus Mutans: A Potential Risk Factor in Recurrent Hemorrhagic Stroke. Cureus.9(5):e1264.

29. Martins AH, Zayas-Santiago A, Ferrer-Acosta Y, Martinez-Jimenez SM, Zueva L, Diaz-Garcia A, et al. (2019). Accumulation of Amyloid Beta (Abeta) Peptide on Blood Vessel Walls in the Damaged Brain after Transient Middle Cerebral Artery Occlusion. Biomolecules.9(8).

30. Peng H, Yang D. (2012). [A boundary element analysis on hemodynamic characteristics at the bifurcation of abdominal arterial]. Sheng wu yi xue gong cheng xue za zhi = Journal of biomedical engineering $=$ Shengwu yixue gongchengxue zazhi.29(4):697-700.

31. Seeger A, Rose K, Ma NT, Kremmer E, Klumpp S, Krieglstein J. (2012). Influence of protein histidine phosphatase overexpression and down-regulation on human umbilical-vein endothelial cell viability. Cell biology international.36(3):245-9.

32. Yalcin HC. (2014). Femtosecond laser photodisruption of vitelline vessels of avian embryos as a technique to study embryonic vascular remodeling. Experimental biology and medicine.239(12):1644-52.

33. Yoon JH, Lee ES, Jeong Y. (2017). In vivo Imaging of the Cerebral Endothelial Glycocalyx in Mice. Journal of vascular research.54(2):59-67.

34. Zhang W, Huang W, Jing F. (2013). Contribution of blood platelets to vascular pathology in Alzheimer's disease. Journal of blood medicine.4:141-7. 